\title{
A Functional Polymorphism in the HMGCR Promoter Affects Transcriptional Activity but not the Risk for Alzheimer Disease in Swedish Populations.
}

\author{
Lina Keller \\ Karolinska Institute \\ Charlotte Murphy \\ Karolinska Institute \\ Steve Meaney \\ Technological University Dublin, steve.meaney@tudublin.ie
}

Follow this and additional works at: https://arrow.tudublin.ie/scschbioart

Part of the Medicine and Health Sciences Commons

\section{Recommended Citation}

Keller,L, Murphy, C.Meaney,S. (2010) A functional polymorphism in the HMGCR promoter affects transcriptional activity but not the risk for Alzheimer disease in Swedish populations. Brain Research, 2010, 1344, pp.185-91. doi:10.1016/j.brainres.2010.04.073.

This Article is brought to you for free and open access by the School of Biological Sciences at ARROW@TU Dublin. It has been accepted for inclusion in Articles by an authorized administrator of ARROW@TU Dublin. For more information, please contact arrow.admin@tudublin.ie, aisling.coyne@tudublin.ie,gerard.connolly@tudublin.ie.

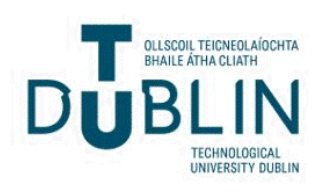




\section{A functional polymorphism in the $H M G C R$ promoter affects transcriptional activity but not the risk for Alzheimer disease in Swedish populations}

Lina Rosvall $^{1 \# \S}$, Charlotte Murphy ${ }^{3 \S}$, Hui-Xin Wang ${ }^{2}$, Laura Fratiglioni ${ }^{2}$, Maria Olin ${ }^{3}$, Mats

Gafvels $^{3}$, Ingemar Björkhem ${ }^{3}$, Caroline Graff ${ }^{2}$ and Steve Meaney ${ }^{3,4 \# \dagger}$

${ }^{1}$ Karolinska Institutet, Department NVS, KI-Alzheimer Disease Research Center, Huddinge,

SE-14157 Stockholm, Sweden. ${ }^{2}$ Aging Research Center, Karolinska Institutet and Stockholm Gerontology Research Center, SE-11330 Stockholm, Sweden; ${ }^{3}$ Division of Clinical

Chemistry, Department of Laboratory Medicine, Karolinska Institutet, Karolinska University Hospital Huddinge, SE-14186 Stockholm, Sweden. ${ }^{4}$ School of Biological Sciences, Faculty of Science, Dublin Institute of Technology, Dublin 8, Ireland.

${ }^{\S}$ These authors contributed equally to this work

${ }^{\#}$ Correspondence:

Steve Meaney, Ph.D.

School of Biological Sciences,

Faculty of Science,

Dublin Institute of Technology,

Ireland.

Tel: +353-1-402(x)4643

Fax: +353-1-402(x)4834

E-mail: Steve.meaney@dit.ie

Pages: 25 Pages including 2 tables

Abstract: 
Variations in genes associated with cholesterol homeostasis have been reported to modify the risk of developing Alzheimer disease (AD). To date there have been few investigations into variations in genes directly involved in cholesterol biosynthesis and AD. We investigated the influence of the -911C >A polymorphism (rs3761740) in the hydroxy-methyl-glutaryl CoA reductase $(H M G C R)$ gene promoter on basal and regulated transcription, plasma cholesterol levels and the association with AD. Under in vitro conditions the A allele was found to be significantly more responsive to SREBP-2 mediated regulation than the $\mathrm{C}$ allele. In an age and sex matched case-control study, the genotype distribution and allele frequency of this polymorphism were not associated with $\mathrm{AD}(\mathrm{OR}=1.03$; $95 \% \mathrm{CI}=0.72-1.48)$. However, we did find evidence supporting an interaction between the HMGCR A allele, the APOE E4 allele and an altered risk of $\mathrm{AD}(\mathrm{OR}=2.41 ; 95 \% \mathrm{CI}=0.93-6.22)$.

Keywords: Alzheimer disease, single nucleotide polymorphism, HMGCR, promoter activity, genetic association, cholesterol. 


\section{Introduction}

Alzheimer disease (AD) is the most common form of dementia. It is a neurodegenerative disease defined histologically by the presence of extracellular neuritic plaques, neuronal loss and intracellular neurofibrillary tangles in the brain. Mutations in three genes - amyloid precursor protein (APP), presenilin 1 (PSEN1) and presenilin 2 (PSEN2) - are known to cause autosomal dominant early-onset AD. However, these mutations account for just a few percent of all AD cases (Goate et al., 1991; Rogaev et al., 1995; Sherrington et al., 1995). While the underlying cause of late-onset $\mathrm{AD}$ (LOAD) remains unknown a number of genetic risk factors have been suggested (see (Tanzi and Bertram, 2005) for a review). The $\varepsilon 4$ allele of apolipoprotein $\mathrm{E}(A P O E)$ has been shown to be a strong independent risk factor in the development of LOAD, and is the only confirmed genetic risk factor for LOAD (Corder et al., 1995; Corder et al., 1998; Poirier et al., 1993; Strittmatter et al., 1993). APOE is a major lipid transport molecule in the central nervous system. Additionally, APOE acts as a scavenger of soluble amyloid and has been hypothesized to play a role in amyloid plaque metabolism and clearance (Beffert and Poirier, 1996; Deane et al., 2008). Very recent genome wide association studies have provided compelling evidence that genetic variations in the apolipoprotein $\mathrm{J}$ gene (also known as clusterin, CLU) are associated with the risk of developing Alzheimer's disease (Harold et al., 2009; Lambert et al., 2009; van Es and van den Berg, 2009)

While all nucleated cells are capable of synthesizing cholesterol, the majority of cells meet their cholesterol requirements via lipoprotein mediated uptake of cholesterol. A notable exception to this is the brain, which synthesises all of the cholesterol it requires in situ, despite accounting for more than one quarter of the body's cholesterol mass. The importance of 
cholesterol for brain function is underscored by the severity of the clinical picture in inherited disorders of cholesterol biosynthesis (see (Hennekam, 2005) for a review). Over the last decade a number of studies have indicated that cholesterol plays a role in AD (see (Hartmann et al., 2007) for a recent review). However, the mechanistic connection(s) between cholesterol and the disease process remain obscure. While cholesterol has been found to influence virtually all of the biochemical processes underlying $\mathrm{AD}$ in vitro, epidemiological studies have shown that elevated midlife serum cholesterol is associated with an increased risk of AD in later life (Kivipelto et al., 2001; Solomon et al., 2007; Stewart et al., 2007).

Numerous studies have investigated the relationship between variants of genes involved in the processes underpinning brain cholesterol homeostasis and AD (Hartmann et al, 2007). Variations in CYP46A1, which encodes cholesterol 24-hydroxylase, a key player in brain cholesterol homeostasis, have been extensively investigated. Intronic polymorphisms in CYP46A1 have been suggested to affect the load of both $\beta$-amyloid and phosphorylated tau protein in the brains of AD patients (Johansson et al., 2004; Papassotiropoulos et al., 2003). However, these association studies have shown inconsistent results concerning variations in the CYP46A1 gene and the risk of AD (Desai et al., 2002; Helisalmi et al., 2006; Ingelsson et al., 2004; Papassotiropoulos et al., 2003). In addition a meta-analysis of the available data does not support a link between genetic variations in CYP46Al and the risk of AD (Llorca et al., 2008).

The availability of the statin class of cholesterol lowering agents has provided a facile means to investigate the influence of cholesterol on the risk of developing $\mathrm{AD}$ and some, but not all, studies have shown a protective effect of statins (Jick et al., 2000; Rea et al., 2005; Wolozin et al., 2000; Zandi et al., 2005). Statins competitively inhibit the rate-limiting enzymatic step in 
cholesterol synthesis, hydroxy-methyl-glutaryl-coenzyme A reductase (HMGCR). Genetic variations in the $H M G C R$ gene have been suggested to modulate the cholesterol lowering response to treatment with statins (Chasman et al., 2004).

Recently a single nucleotide polymorphism (SNP) in the promoter of $H M G C R$ was reported as a risk factor for $\mathrm{AD}$ (Porcellini et al., 2007). As a continuation of our investigations into the molecular mechanisms underlying cholesterol homeostasis we considered it of interest to test the hypothesis that this polymorphism [rs3761740] influences the activity of the HMGCR promoter. Our finding of a strong effect on gene activity prompted us to evaluate the association of this SNP with the risk of AD in a Swedish sample. 


\section{Results}

The $H M G C R$ rs3761740 polymorphism is associated with an increased sensitivity to SREBP

Careful inspection of the HMGCR promoter sequence revealed that the rs3761740 polymorphism was close to a potential SREBP binding site. To determine the effect of this polymorphism on basal and SREBP-2 stimulated promoter activity, we transiently transfected HEK293 cells with pGL3-HMG-A or pGL3-HMG-C. Basal activity of the pGL3-HMG-A was significantly lower $(P<0.001)$ than that of pGL3-HMG-C (see Figure 2a). Subsequent co-transfection with a plasmid expressing the active nuclear form of SREBP-2 resulted in a significantly greater activation $(P<0.001)$ of pGL3-HMG-A compared to pGL3-HMG-C. (Figure 2b). This corresponds to a four-fold induction of promoter activity over basal, in the presence of the A allele and SREBP-2.

\section{The HMGCR rs3761740 polymorphism is not associated with Alzheimer disease in}

\section{Swedish Cases}

Previous studies have reported an association of the rs3761740 polymorphism with AD in an Italian population (Porcellini et al., 2007). In light of our in vitro data we considered it important to verify this data in a well defined, independent Swedish population. No discordance could be detected for samples analysed twice and the success rate of genotyping was $\sim 99 \%$. Neither the case or control sample set diverged from HWE $(p=0.80$ and $p=0.98$, respectively). The frequencies of the $\mathrm{C}$ allele for the controls and $\mathrm{AD}$ cases were $88.9 \%$ and $89.2 \%$, respectively (for genotype frequencies see Table 1), which is consistent with the previous results from Porcellini et al (Porcellini et al., 2007). Unsurprisingly, the $\varepsilon 4$ allele of 
$A P O E$ was present in $61 \%$ of the cases and $26 \%$ of the controls and the OR for AD for those with the $\varepsilon 4$ allele was 5.3 , adjusted for cholesterol levels.

Mean cholesterol levels were significantly lower in patients than in controls $(5.62 \pm 1.15 \mathrm{mM}$ vs. $5.90 \pm 1.08 \mathrm{mM}, P=0.002)$. When combining $\mathrm{AD}$ cases and controls, and adjusting for age, gender and disease status, carriers of the $A P O E \varepsilon 4$ allele had significantly higher cholesterol levels than $\varepsilon 4$ negative individuals $(5.97 \pm 1.15 \mathrm{mM}$ vs. $5.69 \pm 1.09 \mathrm{mM}$, $\mathrm{F}(1,604)=11.18, \mathrm{p}<0.001)$. No difference was detected in cholesterol levels between $\mathrm{A}$ carriers and non-A carriers of the $H M G C R$ rs3761740 polymorophism $(\mathrm{F} 91,601)=0.09, \mathrm{p}=$ 0.76). Analysis of the total case-control series did not reveal a significant association between presence of an A allele (i.e. AA+AC), compared with homozygosity for the $\mathrm{C}$ allele, and risk for $\mathrm{AD}$ (unadjusted $\mathrm{OR}=1.03 ; 95 \% \mathrm{CI}=0.72-1.48 ; P=0.86$ ). However, we did notice a tendency towards an interaction between the APOE $\varepsilon 4$ and HMGCR -911A alleles in relation to $\mathrm{AD}(\mathrm{OR}=2.41, \mathrm{CI}=0.93-6.22, P=0.07)$. To clarify their relation the two variables were combined in a categorical variable, based on cross tabulation, and introduced in a logistic regression model (see Table 2) Compared with subjects who carry neither APOE $\varepsilon 4$ nor the $H M G C R$-911A allele, the OR for AD was 4.6 for subjects who carry the APOE $\varepsilon 4$ alone, and it was not increased for subjects who carry the $H M G C R-911 \mathrm{~A}$ allele alone. However, when these two genes were present simultaneously, the OR increased to 6.2, approximately $36 \%$ higher than that of carriers of the $A P O E \varepsilon 4$ alone. 


\section{Discussion}

There is strong evidence of an important role for cholesterol in the development of AD (Reid et al., 2007). De novo synthesis of all isoprenoids, including cholesterol, is dependent on the activity of $H M G C R$. In the present work we explored the influence of a promoter polymorphism on the transcriptional activity of the $H M G C R$ gene, on plasma cholesterol levels and on the risk of AD in case and control from Sweden.

Using transient transfection assays with reporter gene constructs of the HMGCR promoter representing either the $\mathrm{C}$ or $\mathrm{A}$ allele, we found a significant effect of the polymorphism on both basal activity and response to SREBP-2. SREBP-2 is considered to be the global regulator of cholesterol synthesis (Horton et al., 2003) and is known to increase HMGCR transcripition (Sakakura et al., 2001). Our results are in contrast to a previous study where no difference between the two alleles was reported (Porcellini et al., 2007). A possible reason for this discrepancy is the type of cell lines used - Porcellini et al used cells derived from adult sources while we used cells of embryonic origin. Additionally, in the study by Porcellini et al Gateway ${ }^{\mathrm{TM}}$ gene recombination technology was used to transfer the cloned promoter into the reporter vector. In this technique 102 bp sequences flank the DNA sequence of interest and permit easy subcloning of the sequence into other vectors. Inspection of these sequences revealed potential binding sites for SREBP, which is known to interact with DNA relatively promiscuously. It is possible that the robust differences we observe in the basal and SREBP regulated reporter activity may have been masked by the presence of these additional sequences in the study by Porcellini et al. 
An intriguing finding of the present work is that, under in vitro conditions, the A allele was significantly more responsive to SREBP-2 compared to the $\mathrm{C}$ allele. If this differential responsiveness is preserved in vivo at both the protein and enzyme activity levels, it would be anticipated that stimulation by SREBP would lead to a greater flux through the cholesterol synthesis pathway in carriers of the minor allele. Given that cholesterol is only one of many isoprenoids downstream of $H M G C R$ activity, this polymorphism may have consequences on other biological processes. In preliminary studies we were unable to demonstrate a difference in lathosterol levels between the two genotypes (results not shown). In the current context it is noteworthy that the major pathway for removal of cholesterol from the brain is sensitive to the flux through the cholesterol synthesis pathway and that a decrease in this flux is associated with profound learning difficulties in mice (Kotti et al., 2006).

We clearly observed lower cholesterol in the plasma of the AD cases than the controls, despite the fact that these samples were not rigorously controlled for prandial status or drug treatment. This is in general agreement with previous epidemiological reports which show elevated mid-life cholesterol levels and decreased levels in later life in AD cases (Stewart et al., 2007). Some studies have also indicated that there may be an association between low plasma cholesterol and AD (Mielke et al., 2005), although these are not universal findings. Given the relatively large numbers of samples involved (even taking into account some missing data) it is unlikely that the observed difference is due to differences in prandial status or dietary intake, and it is known that differences between fasting and non fasting cholesterol are relatively small (Craig et al., 2000; Di Angelantonio et al., 2009). Despite this, it is possible that over the long term, differences in dietary habits may contribute to the observed changes. It is worth noting, however, that these are not isolated findings and a recent paper from Soloman et al revealed a tendency towards lower cholesterol levels in AD patients 
(Solomon et al., 2009). Comparison of the cholesterol levels between APOE $\varepsilon 4$ carriers and non-carriers revealed that individuals carrying the $\varepsilon 4$ allele (cases and controls together) had a tendency towards higher levels of cholesterol than those without $(P=0.054)$, in line with findings from previous studies (reviewed in (Hagberg et al., 2000; Ordovas and Mooser, 2002)).

We were unable to replicate the previous finding that the A allele is associated with $\mathrm{AD}$ (Porcellini et al., 2007). It should be noted that although Porcellini et al reported an association for their entire population, the effect appears to be due to an increased frequency of the A allele in $\mathrm{AD}$ cases without an $A P O E \varepsilon 4$ allele. The above results may be confounded by an under-representation of $A P O E \varepsilon 4$ carriers due to the established decrease in $A P O E \varepsilon 4$ allele frequencies from northern to southern Europe. In the present work we found an increase in risk for $\mathrm{AD}$ in individuals carrying the combination of $\varepsilon 4$ and an $\mathrm{A}$ allele, compared to $\varepsilon 4$ negative A carriers. While we were unable to formally demonstrate an interaction between these genes $(P=0.07)$ we consider this to be a biologically relevant interaction that warrants further investigation ( $c f$ below). In support of our findings, a recent genome wide association study, performed to identify new loci that influence lipid concentrations (Willer et al., 2008), failed to identify the $H M G C R$ gene as a potential modifier of cholesterol concentrations using Affymetrix and Illumina arrays that each contained the polymorphism of interest (rs3761740).

The interpretation of the biochemical consequences of a potential interaction between variations in the $A P O E$ and the $H M G C R$ genes is difficult, particularly given our poor understanding of the mechanisms underpinning brain cholesterol homeostasis. However, it can be speculated that the decreased basal cholesterol synthesis would lead to a decreased lipidation of APOE containing lipoproteins. In addition, the dependence of APOE secretion 
on prenylation is well established (Naidu et al., 2002), suggesting reduced flux through the mevalonate pathway may have multiple effects on APOE secretion. A very recent study reported that total brain APOE levels are influenced by the APOE genotype, with APOE4 associated with lowest levels (Riddell et al., 2008). The combination of the APOE $\varepsilon 4$ and $H M G C R$ A alleles may thus influence the both the production and release of cholesterol from astrocytes, which are believed to be the major site of both cholesterol and APOE synthesis in the brain (Pfrieger, 2003). Ultimately this may influence the availability of cholesterol within the central nervous system. Moreover, the low basal activity of the A allele of $H M G C R$ may contribute to a decreased cholesterol biosynthesis, a perceived cholesterol deficiency and an activation of SREBP-2. Given the apparent sensitivity of the A allele to SREBP-2 mediated regulation, in the presence of APOE $\varepsilon 4$ this may lead to a scenario where cholesterol is produced but not secreted, leading to cholesterol based dysfunction of astroglial cells. It is noteworthy that such astroglial activation occurs in Niemann Pick Disease Type-C, a cholesterol storage disease that presents histologically with neurofibrillary tangles identical to those in AD (Love et al., 1995). In support of potential interactions between APOE and HMGCR, a recent study by Recuero et al (Recuero et al., 2009) found that there was a trend towards a link between an a 3' SNP in the HMGCR gene and APOE, in that the greatest decrease in risk was present in APOE $\varepsilon 4$ carrier women.

This is the first study to show that the $-911 \mathrm{C}>\mathrm{A}$ polymorphism in the promoter region of the $H M G C R$ gene has a functional role for the transcriptional activity. The SNP has not previously been investigated for its effect on plasma cholesterol levels or on the risk for AD in Swedish populations. Although we were unable to find differences in plasma cholesterol levels between carriers of the different alleles or an association to $\mathrm{AD}$, our results suggest that the A allele of the HMGCR -911 C>A SNP may act together with the APOE $\varepsilon 4$ allele to 
increase the risk of $\mathrm{AD}$ in a manner which is independent of its effect on plasma cholesterol levels. Further studies are required to confirm or refute this hypothesis. 


\section{Materials and Methods}

\section{Cloning and analysis of the human $H M G C R$ promoter}

A DNA fragment corresponding to bp -1221 to +85 of the human $H M G C R$ promoter and containing the polymorphism of interest [rs3761740] (Figure 1) was amplified by PCR using Phusion $^{\mathrm{TM}}$ High-Fidelity DNA polymerase (Finnzyme Oy, Finland) using purified human genomic DNA as a template and the primers HMGCR-F (5'TCCTTAATAAATTTCCACATACGATAG-3') and HMGCR-R (5’CCTCACCTCCAGATCTCACTAGA-3’). Adenosine overhangs were added after the initial PCR step using Dynazyme EXT and dATP (Finnzyme Oy, Finland). The PCR product was purified and ligated into pCR2.1 plasmid according to standard techniques. After combined SacI and XhoI digestion a 1306 bp DNA fragment was released and subsequently directionally inserted into the pGL3 basic vector (Promega Biotech AB, Nacka, Stockholm) to yield pGL3-HMG-C. To create the corresponding A containing vector pGL3-HMG-C was mutated using site directed mutagenesis and the following primers: MutFoward $-5^{\prime}-$

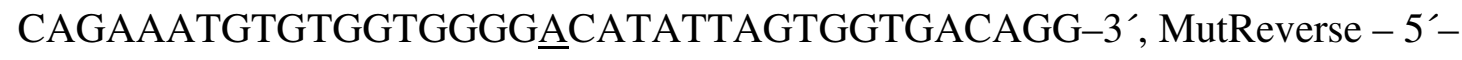
CCTGTCACCACTAATATGTCCCCACCACACATTTCTG-3’ (the mutated bases are underlined). The resulting plasmid was designated pGL3-HMG-A. The integrity of all constructs was verified by DNA sequencing with 2-fold coverage (Cybergene AB, Huddinge, Sweden).

Human embryonic kidney cells (HEK 293; ATCC Catalog No. CRL-1573, American Type Culture Collection, Manassas, USA) were cultured at $37^{\circ} \mathrm{C}$ in Dulbecco's Modified Eagle Medium with 10\% (v/v) FBS and Penicillin/Streptomycin (100 IU mL ${ }^{-1} / 100 \mu \mathrm{g} \mathrm{mL}^{-1}$; 
Invitrogen) in an atmosphere of $5 \% \mathrm{CO}_{2}$. Cells were expanded in $175 \mathrm{~cm}^{2}$ flasks and subsequently seeded into 24 -well plates. Cells at $80 \%$ confluence were transfected with the pGL3-HMG reporter gene constructs and co-transfected with either the empty pGL3-basic vector or an SREBP-2 expression plasmid (total DNA 0.3 $\mu \mathrm{g} /$ well) with $\mathrm{Tfx}^{\mathrm{TM}} 20$ Reagent (Promega Biotech AB, Nacka, Stockholm) at a DNA:Tfx20 ratio of 1:3. One hour following the transfection, cells were overlaid with complete medium. Forty hours after transfection cells were lysed and assayed for luciferase activity according to the manufacturer's protocol

using the Luciferase Reporter Gene Assay (Promega Corp USA) and a Wallac 1420 Victor $^{\mathrm{TM}}$ luminometer (Wallac Oy, Turku, Finland). The luciferase measurement was normalised to the protein concentration in each well and is expressed as relative light units/mg total protein. Six independent transfections were performed. Protein concentration determination was performed using the Bradford technique (Bradford, 1976).

\section{Investigation of the association of the HMGCR rs3761740 polymorphism with risk of} Alzheimer Disease

This study was performed on a case-control sample set that was frequency matched for age and gender. 372 cases with LOAD were recruited from the Memory Clinic at Karolinska University Hospital - Huddinge, Sweden. All cases were diagnosed with AD at the age of 67 years or older and the mean age of diagnosis was 79 years. The clinical diagnosis of AD was based on NINCDS-ADRDA criteria (McKhann et al., 1984). The 348 controls were frequency matched for age and gender and selected from an ongoing longitudinal study (The Swedish Study on Aging and Care on Kungsholmen, SNACK (Lagergren et al., 2004)). All control subjects met Mini Mental State Examination exclusion criteria for dementia (cut off MMSE $\geq 28 / 30$ ). The case sample set has been reported previously (Björk et al., 2007). All 
participating subjects, or a proxy, gave informed consent and the study was approved by the local ethics committee.

DNA was extracted from peripheral blood samples obtained during the clinical investigation of memory complaints (AD patients) or during the baseline examination in the SNACK study or during first follow up examination (healthy controls). Samples were genotyped as described above. Genotyping was performed blinded to case and control status which was mixed on each 96-well plate.

Due to the nature of the available samples, total cholesterol was measured without a prior standardized fasting period. Measurements of cholesterol levels in controls were done at the baseline examination while the cholesterol measurement of $\mathrm{AD}$ patients was done during the clinical investigation. In $29 \%$ of the cases and in less than $1 \%$ of the controls cholesterol levels were unavailable.

\section{Statistical analysis}

Statistical analyses were performed using STATA 9.2 statistical software (StatCorp., 2006) or SAS 9.1 (SAS Institute Inc., Cary, NC, USA). Measurements that did not adhere to the Normal Distribution were normalized by logarithmic transformation before statistical analysis. T-test and one-way analysis of variance was used to analyze group differences in plasma biomarkers. All data are presented as mean \pm standard deviation unless otherwise indicated. Exact tests for Hardy Weinberg equilibrium (HWE) were performed on the $H M G C R$ genotypes for cases and controls separately. 
The relationship between the $H M G C R-911 \mathrm{C}>\mathrm{A}$ SNP and the $A P O E \varepsilon 4$ allele and AD was estimated by logistic regression and the results are presented as odds ratios (ORs) with corresponding 95\% CI. All regression models were adjusted for cholesterol levels, unless otherwise stated. Two-way statistical interaction was examined between the HMGCR 911C $>$ A SNP and the APOE $\varepsilon 4$ allele by including the two independent variables and their cross-product terms in the same regression model. To further evaluate the relation between the $A P O E$ \&4 allele, the $H M G C R-911 \mathrm{C}>\mathrm{A}$ SNP and AD a categorical variable was created by combining the genetic information that was included in a logistic regression model. 


\section{Acknowledgements}

This work was supported by the Swedish Research Council, the Heart-Lung Foundation, the Swedish Brain Foundation, Swedish Brain Power, Stockholm County Council (Project 562183), Swedish Council for Working Life and Social Research, The Wallenberg Foundation, Stohnes Foundation, Gamla Tjänarinnor, the Swedish Alzheimer Foundation and the Centre for Health Care Science at Karolinska Institutet. 


\section{Disclosure Statement}

Prof. Caroline Graff is involved in a project (KASPAC) which is a collaboration between Karolinska Institutet and Dainippon Sumitomo Pharma Ltd. However, there are no financial interests in the presented study. There are no other conflicts of interest. 


\section{Footnotes}

${ }^{\dagger}$ Current address:

School of Biological Sciences,

Faculty of Science,

Dublin Institute of Technology,

Kevin Street,

Dublin 8,

Ireland. 


\section{Figure legends:}

Figure 1. Promoter of the human $H M G C R$ gene. The SNP at -911 is denoted by a white C on a grey field. Known sterol response elements present in the human $H M G C R$ promoter are indicated.

Figure 2. Transfection of the human HMGCR reporter constructs into HEK293 cells. A) Cells were transfected with either pGL3-HMGCR-A or pGL3-HMGCR-C respectively ( $n=6)$ using $\mathrm{Tfx}^{\mathrm{TM}} 20$ reagent. B) Cells were co-transfected with either empty pGL3-Basic of an expression plasmid for SREBP-2. 40hr post transfection, cells were lysed and the lysates assayed for luciferase activity. All values are expressed as means \pm standard error of the mean. 
Table 1. Genotype distribution of the $H M G C R$ rs3761740 polymorphism in healthy controls and $\mathrm{AD}$ cases.

\begin{tabular}{|c|c|c|c|}
\hline & Total & Controls & Cases \\
\hline \multicolumn{4}{|c|}{ HMGCR -911C>A, n (\%) } \\
\hline $\mathrm{CC}$ & $566(0.79)$ & $276(0.80)$ & $290(0.79)$ \\
\hline CA & $140(0.20)$ & $67(0.19)$ & $73(0.20)$ \\
\hline AA & $8(0.01)$ & $4(0.01)$ & $4(0.01)$ \\
\hline \multicolumn{4}{|c|}{ APOE ع4, n (\%) ${ }^{1}$} \\
\hline Non-ع4 & $400(0.56)$ & $257(0.74)$ & $143(0.39)$ \\
\hline$\varepsilon 4$ & $313(0.44)$ & $90(0.26)$ & $223(0.61)$ \\
\hline
\end{tabular}


Table 2. OR and 95\% confidence intervals (CI) for AD according to presence of the APOE $\varepsilon 4$ allele and the $H M G C R-911 \mathrm{~A}$ allele.

\begin{tabular}{lllllr}
\hline APOE ₹4 & HMGCR A & Subjects & AD Cases & $\mathrm{OR}^{\#}(95 \% \mathrm{Cl})$ & P value \\
\hline No & No & 288 & 86 & $1.0($ ref $)$ & \\
No & Yes & 68 & 15 & $0.66(0.35-1.24)$ & 0.199 \\
Yes & No & 194 & 123 & $4.57(3.06-6.81)$ & $<0.001$ \\
Yes & Yes & 58 & 40 & $6.21(3.30-11.68)$ & $<0.001$ \\
\hline
\end{tabular}

${ }^{\#}$ ORs are adjusted for cholesterol levels. 


\section{References}

Beffert, U., Poirier, J., 1996. Apolipoprotein E, plaques, tangles and cholinergic dysfunction in Alzheimer's disease. Ann N Y Acad Sci. 777, 166-74.

Björk, B.F., Katzov, H., Kehoe, P., Fratiglioni, L., Winblad, B., Prince, J.A., Graff, C., 2007. Positive association between risk for late-onset Alzheimer disease and genetic variation in IDE. Neurobiol Aging. 28, 1374-80.

Bradford, M.M., 1976. A rapid and sensitive method for the quantitation of microgram quantities of protein utilizing the principle of protein-dye binding. Anal Biochem. 72, 248-54.

Chasman, D.I., Posada, D., Subrahmanyan, L., Cook, N.R., Stanton, V.P., Jr., Ridker, P.M., 2004. Pharmacogenetic study of statin therapy and cholesterol reduction. Jama. 291, 2821-7.

Corder, E.H., Saunders, A.M., Pericak-Vance, M.A., Roses, A.D., 1995. There is a pathologic relationship between ApoE-epsilon 4 and Alzheimer's disease. Arch Neurol. 52, 6501.

Corder, E.H., Lannfelt, L., Bogdanovic, N., Fratiglioni, L., Mori, H., 1998. The role of APOE polymorphisms in late-onset dementias. Cell Mol Life Sci. 54, 928-34.

Craig, S.R., Amin, R.V., Russell, D.W., Paradise, N.F., 2000. Blood cholesterol screening influence of fasting state on cholesterol results and management decisions. J Gen Intern Med. 15, 395-9.

Deane, R., Sagare, A., Hamm, K., Parisi, M., Lane, S., Finn, M.B., Holtzman, D.M., Zlokovic, B.V., 2008. apoE isoform-specific disruption of amyloid beta peptide clearance from mouse brain. J Clin Invest.

Desai, P., DeKosky, S.T., Kamboh, M.I., 2002. Genetic variation in the cholesterol 24hydroxylase (CYP46) gene and the risk of Alzheimer's disease. Neurosci Lett. 328, 912.

Di Angelantonio, E., Sarwar, N., Perry, P., Kaptoge, S., Ray, K.K., Thompson, A., Wood, A.M., Lewington, S., Sattar, N., Packard, C.J., Collins, R., Thompson, S.G., Danesh, J., 2009. Major lipids, apolipoproteins, and risk of vascular disease. JAMA. 302, 1993-2000.

Goate, A., Chartier-Harlin, M.C., Mullan, M., Brown, J., Crawford, F., Fidani, L., Giuffra, L., Haynes, A., Irving, N., James, L., et al., 1991. Segregation of a missense mutation in the amyloid precursor protein gene with familial Alzheimer's disease. Nature. 349, 704-6.

Hagberg, J.M., Wilund, K.R., Ferrell, R.E., 2000. APO E gene and gene-environment effects on plasma lipoprotein-lipid levels. Physiol Genomics. 4, 101-108.

Harold, D., Abraham, R., Hollingworth, P., Sims, R., Gerrish, A., Hamshere, M.L., Pahwa, J.S., Moskvina, V., Dowzell, K., Williams, A., Jones, N., Thomas, C., Stretton, A., Morgan, A.R., Lovestone, S., Powell, J., Proitsi, P., Lupton, M.K., Brayne, C., Rubinsztein, D.C., Gill, M., Lawlor, B., Lynch, A., Morgan, K., Brown, K.S., Passmore, P.A., Craig, D., McGuinness, B., Todd, S., Holmes, C., Mann, D., Smith, A.D., Love, S., Kehoe, P.G., Hardy, J., Mead, S., Fox, N., Rossor, M., Collinge, J., Maier, W., Jessen, F., Schurmann, B., van den Bussche, H., Heuser, I., Kornhuber, J., Wiltfang, J., Dichgans, M., Frolich, L., Hampel, H., Hull, M., Rujescu, D., Goate, A.M., Kauwe, J.S., Cruchaga, C., Nowotny, P., Morris, J.C., Mayo, K., Sleegers, K., Bettens, K., Engelborghs, S., De Deyn, P.P., Van Broeckhoven, C., Livingston, G., Bass, N.J., Gurling, H., McQuillin, A., Gwilliam, R., Deloukas, P., Al-Chalabi, A., Shaw, C.E., Tsolaki, M., Singleton, A.B., Guerreiro, R., Muhleisen, T.W., Nothen, M.M., Moebus, S., Jockel, K.H., Klopp, N., Wichmann, H.E., Carrasquillo, M.M., 
Pankratz, V.S., Younkin, S.G., Holmans, P.A., O'Donovan, M., Owen, M.J., Williams, J., 2009. Genome-wide association study identifies variants at CLU and PICALM associated with Alzheimer's disease. Nat Genet. 41, 1088-93.

Hartmann, T., Kuchenbecker, J., Grimm, M.O., 2007. Alzheimer's disease: the lipid connection. J Neurochem. 103 Suppl 1, 159-70.

Helisalmi, S., Vepsalainen, S., Koivisto, A.M., Mannermaa, A., Iivonen, S., Hiltunen, M., Kiviniemi, V., Soininen, H., 2006. Association of CYP46 intron 2 polymorphism in Finnish Alzheimer's disease samples and a global scale summary. J Neurol Neurosurg Psychiatry. 77, 421-2.

Hennekam, R.C., 2005. Congenital brain anomalies in distal cholesterol biosynthesis defects. J Inherit Metab Dis. 28, 385-92.

Horton, J.D., Shah, N.A., Warrington, J.A., Anderson, N.N., Park, S.W., Brown, M.S., Goldstein, J.L., 2003. Combined analysis of oligonucleotide microarray data from transgenic and knockout mice identifies direct SREBP target genes. Proc Natl Acad Sci U S A. 100, 12027-32.

Ingelsson, M., Jesneck, J., Irizarry, M.C., Hyman, B.T., Rebeck, G.W., 2004. Lack of association of the cholesterol 24-hydroxylase (CYP46) intron 2 polymorphism with Alzheimer's disease. Neurosci Lett. 367, 228-31.

Jick, H., Zornberg, G.L., Jick, S.S., Seshadri, S., Drachman, D.A., 2000. Statins and the risk of dementia. Lancet. 356, 1627-31.

Johansson, A., Katzov, H., Zetterberg, H., Feuk, L., Johansson, B., Bogdanovic, N., Andreasen, N., Lenhard, B., Brookes, A.J., Pedersen, N.L., Blennow, K., Prince, J.A., 2004. Variants of CYP46A1 may interact with age and APOE to influence CSF Abeta42 levels in Alzheimer's disease. Hum Genet. 114, 581-7.

Kivipelto, M., Helkala, E.L., Laakso, M.P., Hanninen, T., Hallikainen, M., Alhainen, K., Soininen, H., Tuomilehto, J., Nissinen, A., 2001. Midlife vascular risk factors and Alzheimer's disease in later life: longitudinal, population based study. Bmj. 322, 1447 51.

Kotti, T.J., Ramirez, D.M., Pfeiffer, B.E., Huber, K.M., Russell, D.W., 2006. Brain cholesterol turnover required for geranylgeraniol production and learning in mice. Proc Natl Acad Sci U S A. 103, 3869-74.

Lagergren, M., Fratiglioni, L., Hallberg, I.R., Berglund, J., Elmstahl, S., Hagberg, B., Holst, G., Rennemark, M., Sjolund, B.M., Thorslund, M., Wiberg, I., Winblad, B., Wimo, A., 2004. A longitudinal study integrating population, care and social services data. The Swedish National study on Aging and Care (SNAC). Aging Clin Exp Res. 16, 158-68.

Lambert, J.C., Heath, S., Even, G., Campion, D., Sleegers, K., Hiltunen, M., Combarros, O., Zelenika, D., Bullido, M.J., Tavernier, B., Letenneur, L., Bettens, K., Berr, C., Pasquier, F., Fievet, N., Barberger-Gateau, P., Engelborghs, S., De Deyn, P., Mateo, I., Franck, A., Helisalmi, S., Porcellini, E., Hanon, O., de Pancorbo, M.M., Lendon, C., Dufouil, C., Jaillard, C., Leveillard, T., Alvarez, V., Bosco, P., Mancuso, M., Panza, F., Nacmias, B., Bossu, P., Piccardi, P., Annoni, G., Seripa, D., Galimberti, D., Hannequin, D., Licastro, F., Soininen, H., Ritchie, K., Blanche, H., Dartigues, J.F., Tzourio, C., Gut, I., Van Broeckhoven, C., Alperovitch, A., Lathrop, M., Amouyel, P., 2009. Genome-wide association study identifies variants at CLU and CR1 associated with Alzheimer's disease. Nat Genet. 41, 1094-9.

Llorca, J., Rodriguez-Rodriguez, E., Dierssen-Sotos, T., Delgado-Rodriguez, M., Berciano, J., Combarros, O., 2008. Meta-analysis of genetic variability in the beta-amyloid production, aggregation and degradation metabolic pathways and the risk of Alzheimer's disease. Acta Neurol Scand. 117, 1-14. 
Love, S., Bridges, L.R., Case, C.P., 1995. Neurofibrillary tangles in Niemann-Pick disease type C. Brain. 118 ( Pt 1), 119-29.

McKhann, G., Drachman, D., Folstein, M., Katzman, R., Price, D., Stadlan, E.M., 1984. Clinical diagnosis of Alzheimer's disease: report of the NINCDS-ADRDA Work Group under the auspices of Department of Health and Human Services Task Force on Alzheimer's Disease. Neurology. 34, 939-44.

Mielke, M.M., Zandi, P.P., Sjogren, M., Gustafson, D., Ostling, S., Steen, B., Skoog, I., 2005. High total cholesterol levels in late life associated with a reduced risk of dementia. Neurology. 64, 1689-95.

Naidu, A., Xu, Q., Catalano, R., Cordell, B., 2002. Secretion of apolipoprotein E by brain glia requires protein prenylation and is suppressed by statins. Brain Res. 958, 100-11.

Ordovas, J.M., Mooser, V., 2002. The APOE locus and the pharmacogenetics of lipid response. Curr Opin Lipidol. 13, 113-7.

Papassotiropoulos, A., Streffer, J.R., Tsolaki, M., Schmid, S., Thal, D., Nicosia, F., Iakovidou, V., Maddalena, A., Lutjohann, D., Ghebremedhin, E., Hegi, T., Pasch, T., Traxler, M., Bruhl, A., Benussi, L., Binetti, G., Braak, H., Nitsch, R.M., Hock, C., 2003. Increased brain beta-amyloid load, phosphorylated tau, and risk of Alzheimer disease associated with an intronic CYP46 polymorphism. Arch Neurol. 60, 29-35.

Pfrieger, F.W., 2003. Outsourcing in the brain: do neurons depend on cholesterol delivery by astrocytes? Bioessays. 25, 72-8.

Poirier, J., Davignon, J., Bouthillier, D., Kogan, S., Bertrand, P., Gauthier, S., 1993. Apolipoprotein E polymorphism and Alzheimer's disease. Lancet. 342, 697-9.

Porcellini, E., Calabrese, E., Guerini, F., Govoni, M., Chiappelli, M., Tumini, E., Morgan, K., Chappell, S., Kalsheker, N., Franceschi, M., Licastro, F., 2007. The hydroxy-methylglutaryl CoA reductase promoter polymorphism is associated with Alzheimer's risk and cognitive deterioration. Neurosci Lett. 416, 66-70.

Rea, T.D., Breitner, J.C., Psaty, B.M., Fitzpatrick, A.L., Lopez, O.L., Newman, A.B., Hazzard, W.R., Zandi, P.P., Burke, G.L., Lyketsos, C.G., Bernick, C., Kuller, L.H., 2005. Statin use and the risk of incident dementia: the Cardiovascular Health Study. Arch Neurol. 62, 1047-51.

Recuero, M., Vicente, M.C., Martinez-Garcia, A., Ramos, M.C., Carmona-Saez, P., Sastre, I., Aldudo, J., Vilella, E., Frank, A., Bullido, M.J., Valdivieso, F., 2009. A free radicalgenerating system induces the cholesterol biosynthesis pathway: a role in Alzheimer's disease. Aging Cell. 8, 128-39.

Reid, P.C., Urano, Y., Kodama, T., Hamakubo, T., 2007. Alzheimer's disease: cholesterol, membrane rafts, isoprenoids and statins. J Cell Mol Med. 11, 383-92.

Riddell, D.R., Zhou, H., Atchison, K., Warwick, H.K., Atkinson, P.J., Jefferson, J., Xu, L., Aschmies, S., Kirksey, Y., Hu, Y., Wagner, E., Parratt, A., Xu, J., Li, Z., Zaleska, M.M., Jacobsen, J.S., Pangalos, M.N., Reinhart, P.H., 2008. Impact of apolipoprotein E (ApoE) polymorphism on brain ApoE levels. J Neurosci. 28, 11445-53.

Rogaev, E.I., Sherrington, R., Rogaeva, E.A., Levesque, G., Ikeda, M., Liang, Y., Chi, H., Lin, C., Holman, K., Tsuda, T., et al., 1995. Familial Alzheimer's disease in kindreds with missense mutations in a gene on chromosome 1 related to the Alzheimer's disease type 3 gene. Nature. 376, 775-8.

Sakakura, Y., Shimano, H., Sone, H., Takahashi, A., Inoue, N., Toyoshima, H., Suzuki, S., Yamada, N., 2001. Sterol regulatory element-binding proteins induce an entire pathway of cholesterol synthesis. Biochem Biophys Res Commun. 286, 176-83.

Sherrington, R., Rogaev, E.I., Liang, Y., Rogaeva, E.A., Levesque, G., Ikeda, M., Chi, H., Lin, C., Li, G., Holman, K., et al., 1995. Cloning of a gene bearing missense mutations in early-onset familial Alzheimer's disease. Nature. 375, 754-60. 
Solomon, A., Kareholt, I., Ngandu, T., Winblad, B., Nissinen, A., Tuomilehto, J., Soininen, H., Kivipelto, M., 2007. Serum cholesterol changes after midlife and late-life cognition: twenty-one-year follow-up study. Neurology. 68, 751-6.

Solomon, A., Leoni, V., Kivipelto, M., Besga, A., Oksengard, A.R., Julin, P., Svensson, L., Wahlund, L.O., Andreasen, N., Winblad, B., Soininen, H., Bjorkhem, I., 2009. Plasma levels of 24S-hydroxycholesterol reflect brain volumes in patients without objective cognitive impairment but not in those with Alzheimer's disease. Neurosci Lett. 462, 89-93.

StatCorp., 2006. Intercooled Stata 9.2 for Windows, Vol., College Station, USA, pp. TX 77845 .

Stewart, R., White, L.R., Xue, Q.L., Launer, L.J., 2007. Twenty-six-year change in total cholesterol levels and incident dementia: the Honolulu-Asia Aging Study. Arch Neurol. 64, 103-7.

Strittmatter, W.J., Saunders, A.M., Schmechel, D., Pericak-Vance, M., Enghild, J., Salvesen, G.S., Roses, A.D., 1993. Apolipoprotein E: high-avidity binding to beta-amyloid and increased frequency of type 4 allele in late-onset familial Alzheimer disease. Proc Natl Acad Sci U S A. 90, 1977-81.

Tanzi, R.E., Bertram, L., 2005. Twenty years of the Alzheimer's disease amyloid hypothesis: a genetic perspective. Cell. 120, 545-55.

van Es, M.A., van den Berg, L.H., 2009. Alzheimer's disease beyond APOE. Nat Genet. 41, 1047-8.

Willer, C.J., Sanna, S., Jackson, A.U., Scuteri, A., Bonnycastle, L.L., Clarke, R., Heath, S.C., Timpson, N.J., Najjar, S.S., Stringham, H.M., Strait, J., Duren, W.L., Maschio, A., Busonero, F., Mulas, A., Albai, G., Swift, A.J., Morken, M.A., Narisu, N., Bennett, D., Parish, S., Shen, H., Galan, P., Meneton, P., Hercberg, S., Zelenika, D., Chen, W.M., Li, Y., Scott, L.J., Scheet, P.A., Sundvall, J., Watanabe, R.M., Nagaraja, R., Ebrahim, S., Lawlor, D.A., Ben-Shlomo, Y., Davey-Smith, G., Shuldiner, A.R., Collins, R., Bergman, R.N., Uda, M., Tuomilehto, J., Cao, A., Collins, F.S., Lakatta, E., Lathrop, G.M., Boehnke, M., Schlessinger, D., Mohlke, K.L., Abecasis, G.R., 2008. Newly identified loci that influence lipid concentrations and risk of coronary artery disease. Nat Genet. 40, 161-9.

Wolozin, B., Kellman, W., Ruosseau, P., Celesia, G.G., Siegel, G., 2000. Decreased prevalence of Alzheimer disease associated with 3-hydroxy-3-methyglutaryl coenzyme A reductase inhibitors. Arch Neurol. 57, 1439-43.

Zandi, P.P., Sparks, D.L., Khachaturian, A.S., Tschanz, J., Norton, M., Steinberg, M., WelshBohmer, K.A., Breitner, J.C., 2005. Do statins reduce risk of incident dementia and Alzheimer disease? The Cache County Study. Arch Gen Psychiatry. 62, 217-24. 
Figure 1

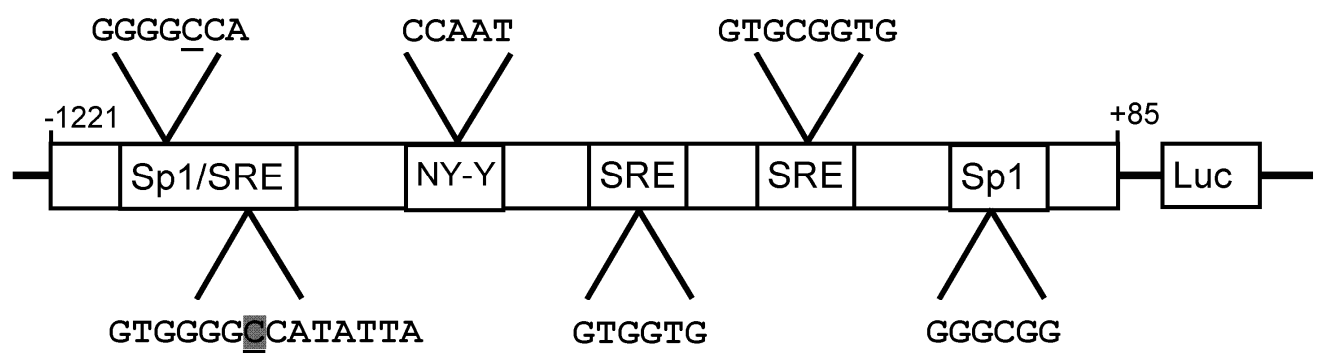


Figure 2A

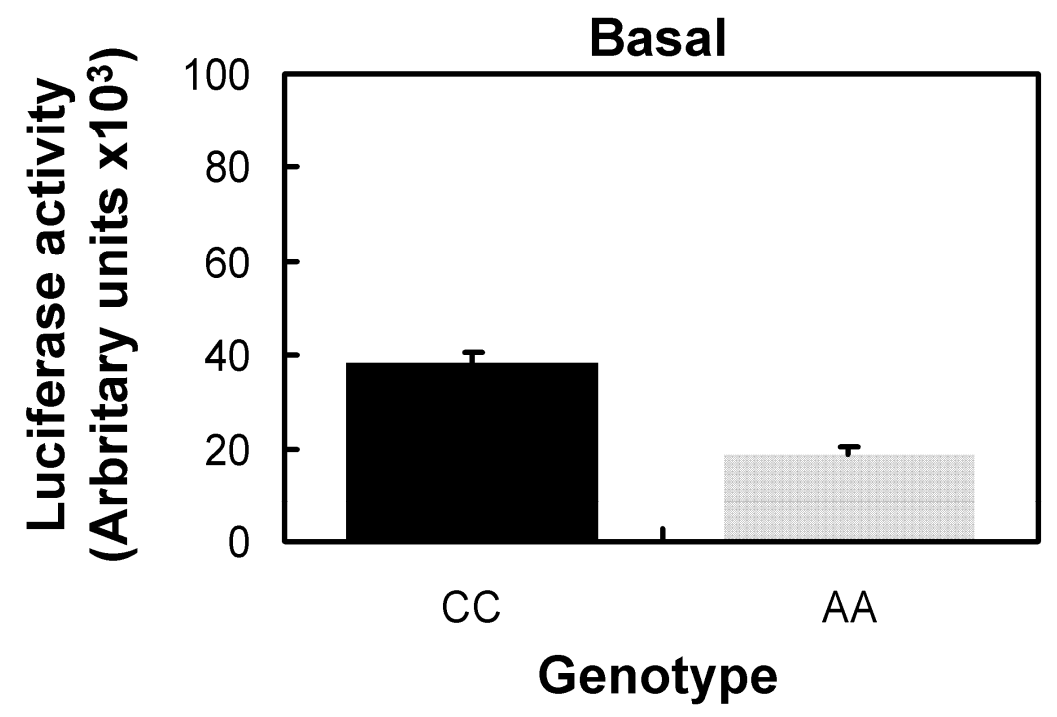

Figure 2B

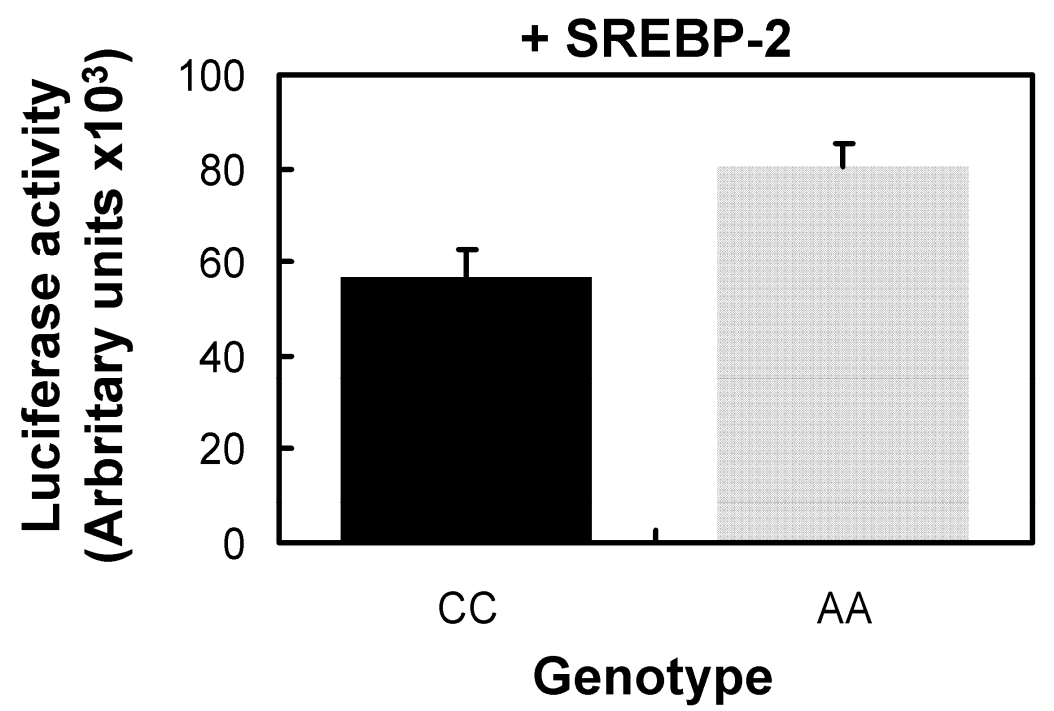

